\title{
PENGARUH NILAI TUKAR RUPIAH DAN PRODUK DOMESTIK BRUTO TERHADAP NILAI EKSPOR TEMBAKAU DI INDONESIA TAHUN 1986-2016
}

\author{
Tarmizi Abbas ${ }^{\mathrm{a}^{*}}$, Desi Irayani* \\ ${ }^{a}$ Fakultas Ekonomi dan Bisnis Universitas Malikussaleh \\ *Corresponding author:
}

A B S T R A C T

Keywords:

Tobacco Export, Exchange Rate, Gross

Domestic Product (GDP)
The study aims to determine the effect of the rupiah exchange rate and gross domestic product $(G D P)$ on the value of tobacco exports in Indonesia. The data used in the study are secondary data from 1986-2016. The data analysis method used in the research is the model a Multiple Linear Regression. The results show that the rupiah exchange rate and gross domestic product (GDP) significantly influence the value of tobacco exports in Indonesia

\section{PENDAHULUAN}

Ekspor adalah salah satu sektor perekonomian yang memegang penting bagi suatu negara, karena dengan adanya ekspor suatu negara dapat memperluas pasar baik perluasan dalam sektor industri maupun sektor ekonomi lainnya(Baldwin, 2005).Makna inti dari ekspor yang paling utama ialah kegiatan dimana suatu negara menjual barang atupun jasa ke luar negeri dengan motif atau tujuan yaitu mencari keuntungan baik keuntungan bagi perusahaan, individu, maupun keuntungan bagi negara. Secara umum dapat dikatakan bahwasannyaapabila semakin banyak jenisbarang yang memiliki keistimewaan yangdiproduksikan oleh suatu negara, maka semakin banyak pula barang yang nantinya akan diekspor oleh negara tersebut (Sukirno, 2008).

Di Indonesia sendiri jenis barang yang diekspor itu terdiri atas 2antara lain migas dan nonmigas.Barang-barang yang dapat dikategorikan kedalam jenis migas adalahbensin, minyak tanah dan solar, serta elpiji. Sedangkan barang-barang yang dapat dikategorikan kedalam jenis nonmigas adalahbarang yang dhasilkan dari laut seperti ikan serta kerang, hasil dari sektor industri, hasil dari tambang nonmigas dan barangyang diproduksikan dari sektor pertanian dan perkebunan, seperti tembakau.

Data FAO pada tahun 2016 menunjukkan bahwa Indonesia adalah salah satu dari 10 negara yang memproduksi tembakau terbesar di dunia. Perdagangan internasional mengharuskan negaranegarauntuk memiliki spesialisasi produk dan juga berkemampuan untuk bisa bersaing memperebutkan pasar yang ada.

Salvatore (2007)menyatakan bahwa salah satu variabel yang mempengaruhi nilai ekspor tembakau di Indonesia yaitu Nilai tukar (Kurs). Nilai tukar adalah nilai atau harga dari mata uang suatu negara yang dibandingkan dengan harga dari mata uang negara lain. Ketidakstabilan nilai tukar berpengaruh terhadap arus modal, investasi dan berpengaruh terhadap perdagangan internasional (Triyono, 2008). Penurunan nilai suatu mata uang dinamakan depresiasi, sedangkan peningkatan nilaisuatu mata uang dinamakan apresiasi. Perubahan dari suatu nilai tukar dalam satu sisi apabila terjadi depresiasi mata uang maka akan berpengaruh terhadap meningkatnnya kinerja ekspor dimana suatu negara akan memperperbesar kapasitas ekspor dan kemudian menekan impor. Begitupun sebaliknya apabila yang terjadi yaitu apresiasi nilai suatu mata uang maka akan berpengaruh sebaliknya (Sukirno, 2010).

Nilai tukar rupiah yang menguat berdampak positif terhadap transaksi ekonomi dalam negeri, masyarakat akan cenderung memperbesar impor dan memperkecil ekspor. Kondisi rupiah yang menguat membuat keuntungan yang diperoleh 
produsen tembakau menurun. Dengan demikian maka hal ini berati bahwa fluktuasi nilai tukar rupiah dan kondisi perokonomian global yang tidak menentu sangat berpengaruh pada kinerja ekspor, salah satunya adalah ekspor tembakau.

Selain nilai tukar rupiah, ekspor tembakau juga dipengaruhi oleh Produk Domestik Bruto (PDB). Apabila PDB Indonesia meningkat maka tingkat konsumsi tembakau juga akan meningkat hal ini disebabkan oleh meningkatnya daya beli masyarakat. Meningkatnya modal dan investasi membuat produsen tembakau memperbesar kapasitas produksinya. Peningkatan jumlah produksi tembakau yang disebabkan oleh meningkatnya PDB akan mendorong meningkatnya jumlah tembakau yang di ekspor. Hal ini dikarenakan ekspor berkaitan dengan adanya surplus atau kelebihan hasil output produksi dalam negeri.

Untuk lebihjelasnya dapat dilihat pada Tabel 1.1 mengenai perkembangan nilai tukar rupiah, produk domestik bruto dan nilai ekspor tembakau di Indonesia tahun 2014-2016, sebagai berikut:

Tabel 1.1

Perkembangan Nilai Tukar Rupiah, Produk Domestik Bruto dan Nilai Ekspor Tembakau Di Indonesia Tahun 2014-2016

\begin{tabular}{|c|c|c|c|}
\hline Tahun & $\begin{array}{c}\text { Nilai Tukar } \\
\text { Rupiah } \\
\text { (Terhadap US\$) }\end{array}$ & $\begin{array}{c}\text { Produk } \\
\text { Domestik Bruto } \\
\text { (Milyar Rupiah) }\end{array}$ & $\begin{array}{c}\text { Nilai Ekspor } \\
\text { Tembakau } \\
\text { (000 US\$) }\end{array}$ \\
\hline 2014 & 11865,21 & 8.564 .866 .60 & 181.323 \\
\hline 2015 & 13389,41 & 8.982 .511 .30 & 156.784 \\
\hline 2016 & 13308,33 & 9.433 .034 .40 & 95.236 \\
\hline
\end{tabular}

Sumber: 1. http://www.worldbank.org/

2. https://bps.go.id

Tabel 1.1 menunjukkan bahwa perkembangan nilai tukar rupiah dari tahun 20142015 terus melemah dengan nilai yang cukup drastis yaitu dari Rp.11.865,21 menjadi Rp.13.389,41. Sementara PDB terus mengalami peningkatan selama 3 tahun terakhir ini yaitu Rp.8.564.866.60 pada tahun 2014 menjadi Rp.9.433.034.40 pada tahun 2016.

Dari data diatas dapat disimpulkan bahwasannya kondisi nilai tukar yang terdepresiasi seharusnya berdampak meningkatkan nilai ekspor tembakau. Namun yang terjadi justru sebaliknya yaitu menurunkan nilai ekspor tembakau yang diekspor oleh Indonesia.Kondisi ini berarti menandakan bahwa fenomena yang terjadi bertentangan dengan teori yang telah dikemukakan olehSukirno (2000)yaitu jika kurs mata uang suatu negara mengalami depresiasi maka negara tersebut akan memperbesar kapasitas ekspor.

Sama halnya dengan teori yang telah dikemukakan oleh Boediono (2001), apabila nilai rupiah terdepresiasi terhadap mata uang dari negara lain maka akan berdampak pada nilai ekspor yang naik sedangkan nilai impornya akan turun. Dari kedua pernyataan diatas maka sudah jelas bahwa fenomena ini bertentangan dengan teori yang ada. Seharusnya Nilai tukar rupiah berhubungan secara negatif terhadap ekspor tembakau, namun dari data yang ada justru yang terjadi adalah sebaliknya.

Berdasarkan uraian diatas, maka penulis tertarik untuk meneliti dan membahas lebih lanjut mengenai fenomena yang terjadi mengenai Nilai Ekspor Tembakau dalam sebuah judul penelitian "Pengaruh Nilai Tukar Rupiah dan Produk Domestik Bruto Terhadap Nilai Ekspor Tembakau Di Indonesia Tahun 1986-2016".

Perbedaan penelitian ini dengan penelitian sebelumnya yang dilakukan oleh Kadek Dwi Arya Pramanta, dkk (2017) yaitu menggunakan variabel negara tujuan, produksi, ekspor ikan tuna.

Persamaan dengan penelitian sebelumnya menggunakan nilai tukar rupiah, PDB, dan ekspor.

Dari uraian diatas dapat disimpulkan bahwa penelitian ini bertujuan untuk mengetahui seberapa besar pengaruh Nilai Tukar Rupiah dan Produk Domestik Bruto terhadap nilai Ekspor Tembakau di Indonesia tahun 1986 - 2016.

\section{KERANGKA TEORITIS Ekspor}

Ekspor merupakansuatu kegiatan yang dilakukan untuk menjual barang maupun jasa ke luar negeri dengan motif utama yaitu untuk mendapatkan keuntungan. MenurutTodaro (2004),definisi ekspor merupakan kegiatan perdagangan internasional yang dapat memberikan rangsangan untuk menumbuhkan atau meningkatkan permintaan dalam negeri yang kemudian menyebabkan tumbuhnya industriindustri pabrik besar, bersama dengan struktur politik yang stabil dan lembaga sosial yang fleksibel. Dengan makna lain bahwa ekspor merupakan kegiatan yang mencerminkan aktifitas 
dari suatu perdagangan internasional, sehingga negara yang berstatus sedang berkembang memiliki kemungkinan untuk mencapai suatu kemajuan dalam perekonomian, yang setara dengan perekonomian negara-negara yang lebih.

\section{Nilai tukar (Exchange Rate)}

Nilai tukar menunjukkan seberapa besar nilai rupiah yang dibutuhkan demi memperoleh uang asing. Menurut Mankiw (2007), kurs merupakan tingkat harga atas dasar kesepakatan penduduk dari dua negara yang saling melakukan perdagangan. Mata uang yang kerapdijadikan sebagai alat pembayaran, sebagai alat kesatuan hitung dalam suatu transaksi ekonomi serta keuangan internasional dinamakanhard currency, yaitu mata uang dengan besaran nilainya relatif stabil jugaterkadang mengalami kenaikan nilai jika dibandingkan dengan nilai dari mata uang lainnya.

\section{Produk Domestik Bruto}

Menurut Sukirno (2006), PDB merupakan nilai dari suatu barang atau jasa didalam satu negara yang dihasilkandari faktor-faktor produksi yang dimiliki oleh warga negara itu sendiri dan warga negara asing.

Menurut Mankiw (2006), PDB dapat dihitung atau dinilai menurut harga pasar atau harga yang berlaku dan harga tetap atau harga konstan. Dalam hal ini, PDB berdasarkan harga berlaku merupakan PDB yang dihitung dengan tidak memperhatikan pengaruh harga.Sementara itu PDB yang berdasarkan atas harga konstanjustru PDB yang dihitung dengan mengoreksi angka dari PDB atas harga berlaku dan memasukkan pengaruh harga.

\section{Hubungan Nilai Tukar Rupiah Terhadap Nilai Ekspor}

Sukirno (2010), mengemukakan bahwa terdapat hubungan negatif antara nilai tukar dengan perdagangan internasional yaitu dari cara fluktuasi nilai tukar yang kemudian mempengaruhi nilai ekspor. Jika kurs suatu negara terapresiasi maka akan terjadi peningkatan impor dan penurunan ekspor yang dilakukan oleh suatu negara. Hal ini dikarenakan harga barang domestik akan cenderung relatif lebih mahal jika dibandingkan dengan harga barang yang sejenis diluar negeri.

Sama halnya dengan teori yang telah dikemukakan oleh Boediono(2001), dimana apabila nilai rupiah terdepresiasi terhadap mata uang dari negara lain maka akan berdampak pada nilai ekspor yang naik sedangkan nilai impornya akan turun. Jika kurs terdepresiasi pasar dalam negeri terlihat menarik dipasaran internasional, harga barang dalam negeri cenderung terlihat lebih murah sehingga nilai ekspor mengalami peningkatan.

\section{Hubungan PDB Terhadap Nilai Ekspor}

Bertambahnya surplus produksi inilah yang mengakibatkan kelebihan hasil barang yang diproduksi akan disalurkan melalui ekspor.

Sukirno (2002) menyatakan bahwa faktor penentu ekspor adalah kemampuan negara tersebut untuk memproduksikan barang yang nantinya dapat bersaing di pasaran luar negeri. Maka dengan meningkatnyaPDB suatu negara, maka jumlah produksi tembakau yang dihasilkan juga akan meningkat. Sehingga Tembakau yang di ekspor oleh Indonesia juga akan semakin meningkat, begitu juga sebaliknya.

\section{Metode Penelitian Objek dan Lokasi Penelitian}

Objek dalam penelitian ini menggunakan nilai tukar rupiah $\left(\mathrm{X}_{1}\right)$ serta produk domestik bruto $\left(\mathrm{X}_{2}\right)$ sebagai variabel bebas atau independent. Menggunakan variabel nilai ekspor tembakau (Y) sebagai variabel terikat atau dependent. Adapun Lokasi penelitian ini dilakukan di Indonesia.

\section{Jenis dan Sumber Data}

Data yang dibutuhkan didalam penelitian ini yaitu data nilai tukar rupiah, produk domestik bruto dan nilai ekspor tembakau di Indonesia dari tahun 1986-2016. Sumber data diperoleh dari publikasi Statistik Indonesia, BPS Indonesia serta studi kepustakaan berbagai literatur yang berkaitan dengan objek penelitian.

\section{Teknik Pengumpulan Data}

Teknik dokumentasi dilakukan dengan mendokumentasikan atau mengarsipkan data-data 
maupun informasi yang berkaitan dengan objek penelitian.

\section{Definisi OperasionalisasiVariabel}

Definisi operasional variabel dalam penelitian ini adalah sebagai berikut:

1. Nilai Ekspor Tembakau (Y), merupakan nilai nominal ekspor tembakau yang diekspor oleh negara Indonesia dalam satuan juta dolar AS (US\$).

2. Nilai Tukar Rupiah/Kurs $\left(X_{1}\right)$, merupakan nilai kurs rupiah terhadap dolar AS yang dinyatakan dalam satuan rupiah $(\mathrm{Rp})$.

3. Produk Domestik Bruto $\left(\mathrm{X}_{2}\right)$, merupakan total nilai produksi barang dan jasa yang diproduksi di Indonesia, dengan satuan rupiah (Rp). Data Produk Domestik Bruto dalam penelitian ini yaitu PDB berdasarkan harga konstan tahun 2000 dan tahun 2010.

\section{METODE PENELITIAN}

\section{Metode Analisis Data}

Untuk menganalisis bagaimana hubungan antar variabel maka pengolahan data menggunakan analisis dengan model Ordinary Least Square (OLS), Model regresilinearberganda menggunakan bantuan program Eviews. Untuk menganalisis hubungan antara variabel bebas dan terikat maka pengolahan data dilakukan dengan menggunakan analisis regresi berganda dimana persamaannya menurut Gujarati (2006) sebagai berikut:

$$
Y=a+\beta_{1} X_{1}+\beta_{2} X_{2}+\text { et }
$$

Dimana:

$\mathrm{Y} \quad=$ Variabel Terikat

$\mathrm{a}=$ Intercept $/$ konstanta

$\beta_{1}, \beta_{2}=$ Koefisien Regresi

$X_{1}, X_{2}=$ Variabel Bebas

et $\quad=$ Variabel Pengganggu

Adapun formulasi modelregresiberganda dalam penelitian ini adalah sebagai berikut:

$$
\begin{aligned}
\text { LnEkspor }= & a+\beta_{1} \operatorname{LnKurs}+\beta_{2} \operatorname{LnPDB} \\
& +\operatorname{LnEkspor}(\mathrm{t}-1)+\text { et }
\end{aligned}
$$

Dimana:

LnEkspor $=$ Nilai Ekspor

Tembakau (US\$)

$\begin{array}{ll}\mathrm{a} & =\text { Intercept } / \text { konstanta } \\ \beta_{1}, \beta_{2} & =\text { Koefisien Regresi } \\ \text { LnKurs }= & \text { Nilai Tukar Rupiah (Rp) } \\ \text { LnPDB = } & \text { Produk Domestik Bruto } \\ & (\mathrm{Rp}) \\ \text { et } & =\end{array}$

\section{HASIL PENELITIAN}

\section{Perkembangan Nilai EksporTembakau}

Ekspor merupakan kegiatan yang di lakukan untuk menjual barang maupun jasa keluar negeri dengan motif atau tujuan untuk mendapatkan keuntungan baik bagi keuntungan bagi suatu perusahaan, individu, maupun keuntungan bagi negara. Di Indonesia sendiri jenis barang yang diekspor itu terdiri atas 2 jenis, yaitu migas dan juga nonmigas seperti ekspor tembakau. Adapun perkembangan Nilai Ekspor Tembakau Indonesia selama Tahun 1986-2016 dapat dilihat pada gambar 4.1.

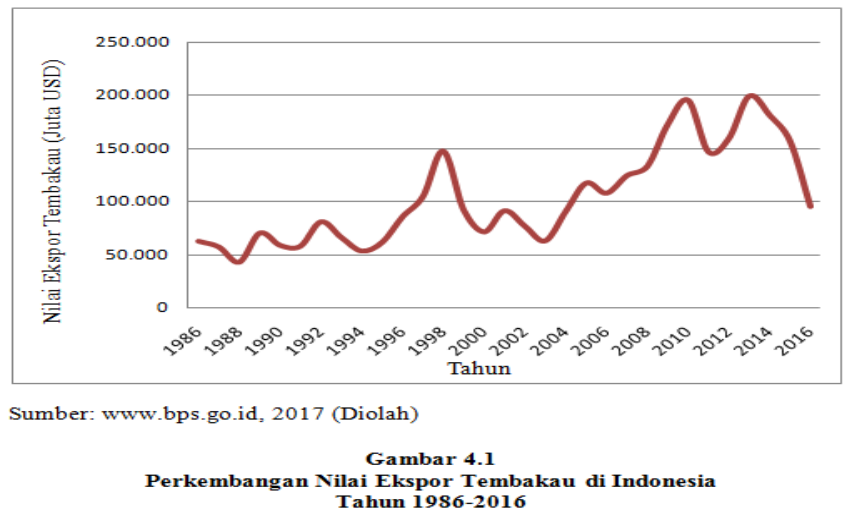

Berdasarkan gambar 4.1, dapat dilihat bahwasannya nilai ekspor tembakau cenderung mengalami fluktuatif dari tahun 1986 hingga 1994, Kemudian pada tahun 1995 hingga tahun 1998 nilai ekspor tembakau terus meningkat dari US\$ 61.4456 menjadi US\$ 147.552. Namun peningkatan ini tidak berlangsung lama, pasalnya pada tahun berikutnya yaitu tahun 1999 nilai ekspor tembakau mengalami penurunan yang terbilang cukup drastis dari US\$ 147.552 menjadi US\$ 91.833. Penurunan ini disebabkan karena kondisi perekonomian global yang krisis.

Selanjutnya pada tahun 2000 hingga 2003 nilai ekspor tembakau terus mengalami penurunan dari US\$ 71.287 menurun menjadi US\$ 62.874 pada tahun 2003.Pada tahun selanjutnya yaitu 
tahun 2004 hingga 2012 kembali mengalami fluktuatif. Selanjutnya pada tahun 2013 hingga tahun 2016 nilai ekspor tembakau terus menurun dari US\$ 199.589 menjadi US\$ 95.236. Dengan demikian, dapat disimpulkn bahwa nilai ekspor tembakau di Indonesia dari tahun 1986-2016 bergerak secara fluktuatif.

\section{Perkembangan Nilai Tukar Rupiah}

Nilai tukar adalah nilai atau harga mata uang antara suatu negara yang selanjutnya dibandingkan dengan harga mata uang negara lain. Sistem kurs valuta asing sangatlah tergantung pada sifat pasar. Peningkatan atau penurunan kurs dollar AS terhadap kurs Rupiah dapat menjadi pemicu naik turunnya ekspor, dalam hal ini adalah tembakau. Adapun perkembangan dari Nilai Tukar Rupiah Terhadap US\$ selama tahun 1986-2016 dapat diperhatikan pada gambar 4.2.

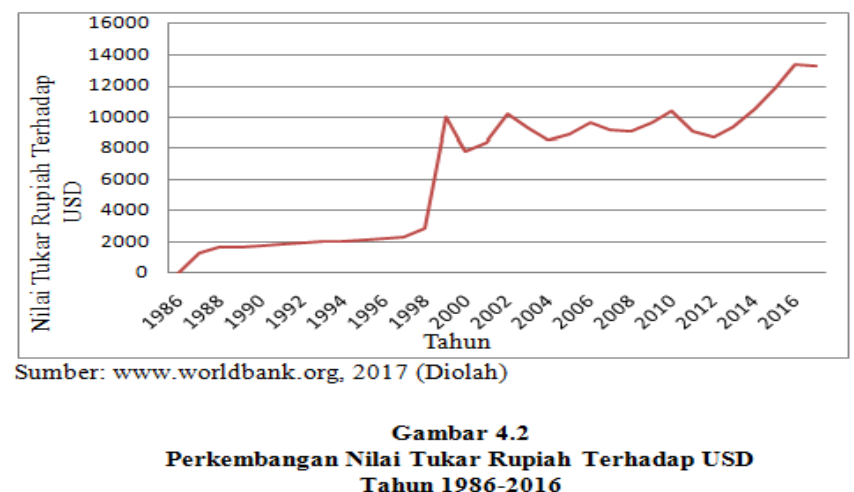

Berdasarkan gambar 4.2, dapat dilihat bahwa nilai tukar rupiah dari tahun 1986 hingga 1998 terus mengalami depresiasi yaitu dari Rp.1.238 menjadi Rp.10.014. Kemudian tahun 1999 sampai tahun 2011 kondisi nilai tukar rupiah mengalami fluktuasi. Selanjutnya pada tahun 2012 hingga 2015 nilai tukar rupiah kembali mengalami depresiasi yaitu dari Rp.8.770 pada 2011 menjadi Rp.13.389 pada tahun 2015. Dan kemudian terapresiasi dalam nilai yang cukup kecil yaitu pada tahun sebelumnya dari Rp.13.389 menjadi Rp.13.308 pada tahun 2016.

Dengan demikian, dapat disimpulkan bahwannya nilai tukar rupiah terhadap dollar AS dari tahun 1986-2016 mengalami fluktuasi dan cenderung mengalami depresiasi dari tahun ke tahun. Hal ini disebabkan oleh berbagai faktor seperti perubahan dari cita rasa masyarakat, perubahan atas harga barang ekspor dan impor, kenaikan harga umum (inflasi), perubahan tingkat suku bunga juga tingkat pengembalian investasi serta pertumbuhan ekonomi.

\section{Perkembangan Produk Domestik Bruto}

PDB adalah nilai dari seluruh barang maupun jasa yang dihasilkan di suatu negara dalam satu tahun tertentu. Adapun perkembangan dari PDB Indonesia dapat dilihat sebagai berikut:

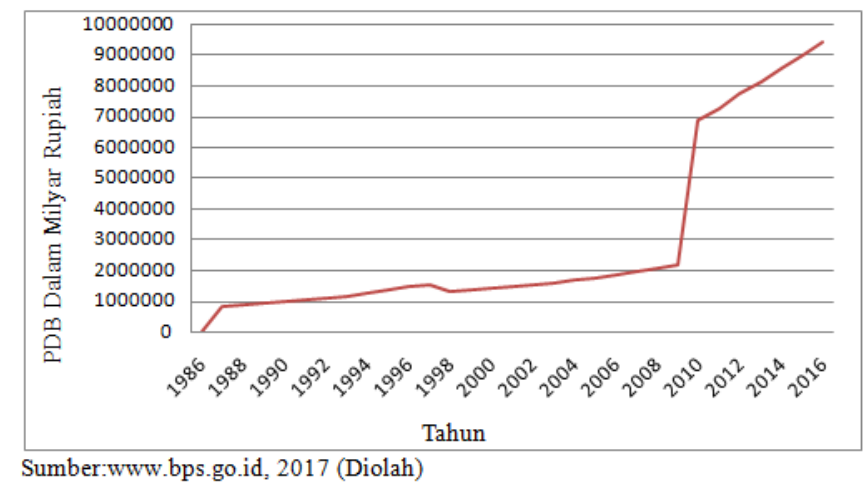

$$
\begin{gathered}
\text { Gambar 4.3 } \\
\text { Perkembangan Produk Domestik Bruto (PDB) Indonesia } \\
\text { Tahun 1986-2016 }
\end{gathered}
$$

Berdasarkan gambar 4.3, dapat dilihat bahwa nilai PDB terus mengalami peningkatan setiap tahunnya. Pada tahun 1986 sampai 2009 Rp.759.644 meningkat menjadi Rp.2.178.850. Pada tahun selanjutnya yaitu tahun 2010 PDB meningkat sangat drastis yaitu dari Rp.2.178.850 pada tahun sebelumnya menjadi Rp.6.864.133 pada tahun 2013. Hal ini dikarenakan pada tahun 1986 hingga 2009 PDB yang digunakan adalah PDB yang berdasarkan harga konstan pada tahun 2000 namun pada tahun selanjutnya yaitu dari tahun 2010 hingga 2016, PDB yang digunakkan adalah PDB yang berdasarkan harga konstan pada tahun 2010. Dari gambar diatas jadi dapat diambil kesimpulan bahwasannya selama tahun 19862016, PDB terus meningkat.

\section{Uji Normalitas}

Pengujian normalitas dengan Jarque-Bera Test mempunyai chisquare dengan derajat bebas dua. Jika hasil Jarque-Bera Test > nilai chi square pada $\alpha=5 \%$, maka tolak $\mathrm{H}_{0}$ yang berarti tidak terdistribusi normal. Jika hasil Jarque-Bera Test<chi square pada $\alpha=5 \%$, maka terima $\mathrm{H}_{0}$ yang berarti error term berdistribusi normal. Berikut ini merupakan hasil dari uji normalitas: 


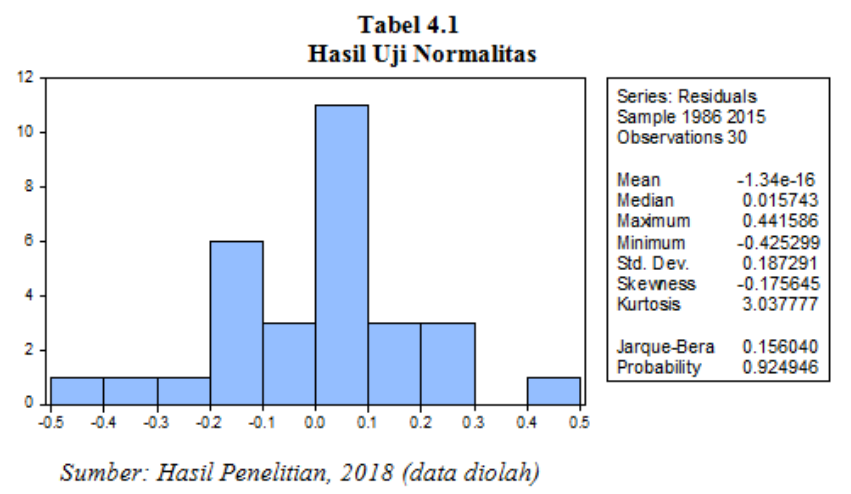

Membandingkan nilai J-B hitung dengan nilai $\mathrm{X}^{2}$ (Chi-Square) tabel adalah sebesar 41.337 bila dibandingkan dengan nilai J-B pada gambar diatas sebesar 0.16 dimana $(0.16<41.337)$. Selain itu hasil analisis menunjukkan bahwa nilai probability sebesar 0,92, oleh karena itu dapat disimpulkan bahwasannya penelitian ini telah terdistribusi normal karena nilai $\mathrm{J}-\mathrm{B}<$ nilai $\mathrm{X}^{2}$ tabel dan serta nilai prob 0,92>0,05.

\section{Analisis Regresi Linier Berganda}

\begin{tabular}{|c|c|c|c|c|}
\hline Variable & Coefficient & Std. Error & t-Statistic & Prob. \\
\hline $\mathrm{C}$ & 2.895980 & 1.039062 & 2.787110 & 0.0098 \\
\hline LKURS & 0.145697 & 0.065861 & 2.212197 & 0.0359 \\
\hline LPDB & 0.224498 & 0.075307 & 2.981113 & 0.0062 \\
\hline LEKSPOR(1) & 0.355235 & 0.133253 & 2.665881 & 0.0130 \\
\hline R-squared & 0.819834 & \multicolumn{2}{|c|}{ Mean dependent var } & 11.46045 \\
\hline Adjusted R-squared & 0.799045 & \multicolumn{2}{|c|}{ S.D. dependent var } & 0.441246 \\
\hline S.E. of regression & 0.197801 & \multicolumn{2}{|c|}{ Akaike info criterion } & -0.279540 \\
\hline Sum squared resid & 1.017261 & \multicolumn{2}{|c|}{ Schwarz criterion } & -0.092714 \\
\hline Log likelihood & 8.193098 & \multirow{2}{*}{\multicolumn{2}{|c|}{$\begin{array}{l}\text { Hannan-Quinn criter. } \\
\text { Durbin-Watson stat }\end{array}$}} & -0.219772 \\
\hline F-statistic & 39.43705 & & & 1.817598 \\
\hline Prob(F-statistic) & 0.000000 & & & \\
\hline
\end{tabular}

Berdasarkan hasil regresi dari Tabel 4.2 diatas model regresi dalam penelitian ini dapat ditulis sebagai berikut:

$$
\begin{gathered}
\text { LEkspor }=2.90+0.15 \text { LKurs }+0.22 \text { LPDB } \\
+0.36 \text { LEkspor }
\end{gathered}
$$

Adapun penjelasan persamaan model adalah sebagai berikut:

1. Konstanta (a) adalah sebesar 2.90 yang artinya apabila Kurs dan PDB dianggap konstan (tetap) sebesar 0, maka nilai ekspor tembakau adalah sebesar 2.90 persen.

2. Nilai Koefisien $\left(\beta_{1}\right)$ adalah sebesar 0.15 , yang artinya apabila Kurs/Nilai tukar rupiah terdepresiasi sebesar satu persen maka nilai ekspor tembakau di Indonesia juga akan meningkat sebesar 0.15 persen.

3. Nilai Koefisien $\left(\beta_{2}\right)$ adalah sebesar 0.22 , yang artinya apabila PDB meningkat satu persen maka nilai ekspor tembakau di Indonesia juga akan meningkat sebesar 0.22 persen.

\section{Uji Asumsi Klasik \\ Uji Autokorelasi}

Tabel 4.3

Hasil Uji Autokorelasi

Breusch-Godfrey Serial Correlation LM Test:

\begin{tabular}{llll}
\hline \hline F-statistic & 1.247257 & Prob. F(2,24) & 0.3053 \\
Obs*R-squared & 2.824563 & Prob. Chi-Square(2) & 0.2436 \\
\hline \hline
\end{tabular}

Sumber: Hasil Penelitian, 2018 (data diolah)

Tabel 4.3 menunjukkan bahwa nilai Prob. Chi-Square(2) pada Obs*R-squared adalah sebesar 0.2436 yang signifikan pada pada $\alpha=5 \%$. Oleh karena itu, dapat disimpulkan bahwasannya model ini terbebas dari uji autokorelasi atau tidak terjadinya autokorelasi karena nilai Prob. ChiSquare(2) $0.2436>0,05$.

\section{Uji Heteroskedastisitas}

\begin{tabular}{llll} 
& \multicolumn{1}{c}{ Tabel 4.4 } \\
Hasil Uji Heteroskedastisitas & \\
Heteroskedasticity Test: White & & \\
\hline \hline F-statistic & 0.985036 & Prob. F(3,26) & 0.4151 \\
Obs*R-squared & 3.061747 & Prob. Chi-Square(3) & 0.3822 \\
Scaled explained SS & 2.343151 & Prob. Chi-Square(3) & 0.5043 \\
\hline \hline Sumber: Hasil Penelitian, 2018 (data diolah)
\end{tabular}

Tabel 4.4 menunjukkan nilai Prob. ChiSquare(3) pada Obs*R-squared yaitu 0.3822 yang signifikan pada $\alpha=5 \%$. Maka dapat disimpulkan bahwasannya model ini sudah terbebas dari uji heteroskedastisitas atau tidak terjadinya heteroskedastisitas, karena nilai Prob. ChiSquare(3) $0.3822>0,05$.

\section{Uji Multikolinieritas}

Berikut ini merupakan hasil dari uji multikolinieritas:

Tabel 4.5

Hasil Uji Multikolinieritas

\begin{tabular}{|c|c|c|}
\hline & LKURS & LPDB \\
\hline LKURS & 1.000000 & 0.694914 \\
\hline
\end{tabular}




\section{\begin{tabular}{l|l|l} 
LPDB & 0.694914 & 1.000000
\end{tabular}}

Sumber: Hasil Penelitian, 2018 (data diolah)

Tabel 4.5 menunjukkan bahwa nilai dari koefisien kolerasi antara kurs dan PDB adalah sebesar $0,70(0,70<0.80)$, maka dapat disimpulkan bahwasannya model ini bebas dari uji multikolinieritas atau tidak terjadinya multikolinieritas antara variabel kurs dan PDB dalam model regresi.

\section{Pembuktian Hipotesis \\ Secara Parsial (Uji t)}

Berdasarkan hasil pengujian yang ditunjukkan pada Tabel 4.5 diatas dapat dilihat bahwasannya nilai tukar rupiah (Kurs) memiliki nilai $t_{\text {hitung }}$ sebesar 2.212197 dengan nilai signifikansi 0.0359 sementara itu, nilai $t_{\text {tabel }}$ dengan $(\mathrm{df})=\mathrm{n}-\mathrm{k}(31-3=28)$ pada $\propto=0,05$ diperoleh nilai sebesar 1.70113. Maka $t_{\text {hitung }}>t_{\text {tabel }}$ yaitu $2.212197>1.70113$, yang berarti menerima $\mathrm{H}_{\mathrm{a} 1}$ dan menolak $\mathrm{H}_{01}$. Dengan demikian maka dapat disimpulkan bahwasannya secara parsial nilai tukar rupiah (Kurs) berpengaruh secara signifikan terhadap nilai ekspor tembakau di Indonesia.

Sedangkan variabel produk domestik bruto (PDB) memiliki nilai thitung sebesar 2.981113 dengan nilai signifikansi 0.0062 sementara nilai $\mathrm{t}_{\text {tabel }}$ dengan $(\mathrm{df})=\mathrm{n}-\mathrm{k}(31-3=28)$ pada $\propto=0,05$ diperoleh nilai sebesar 1.70113. Maka $t_{\text {hitung }}>\mathrm{t}_{\text {tabel }}$ yaitu $2.981113>1.70113$, yang berarti menerima $\mathrm{H}_{\mathrm{a} 2}$ dan menolak $\mathrm{H}_{02}$. Oleh karena itu, maka dapat disimpulkan bahwasnnya secara parsial produk domestik bruto berpengaruh secara signifikan terhadap nilai ekspor tembakau di Indonesia.

\section{Secara Simultan (Uji F)}

Berdasarkan hasil pengujian yang ditunjukkan pada Tabel 4.5, maka dapat dilihat bahwasannya nilai $F_{\text {hitung adalah sebesar } 39.43705}$ dengan nilai signifikansi 0.000000 pada taraf kepercayaan $95 \%$. Sedangkan nilai $\mathrm{F}_{\text {tabel }}$ dengan $\mathrm{df} 1=\mathrm{k}-1(3-1=2)$ dan df2 = n-k $(31-3=28)$ pada derajat $95 \%$ atau $\propto=0,05$ diperoleh nilai sebesar 3.34. Maka $F_{\text {hitung }}>F_{\text {tabel }}$ yaitu $39.43705>3.34$, yang berarti menerima $\mathrm{H}_{\mathrm{a}}$ dan menolak $\mathrm{H}_{0}$. Sehingga dapat disimpulkan bahwa secara simultan (bersama-sama) nilai tukar rupiah dan produk domestik bruto berpengaruh secara signifikan terhadap nilai ekspor tembakau di Indonesia.

\section{KoefisienDeterminasi $\left(\mathbf{R}^{2}\right)$}

Untuk mengetahui besarnya pengaruh nilai tukar rupiah dan produk domestik bruto terhadap nilai ekspor tembakau di Indonesia dapat dilihat pada nilai $\left(\mathrm{R}^{2}\right)$. Berdasarkan hasil pengujian pada Tabel 4.5 maka dapat dilihat bahwasannya nilai $\mathrm{R}^{2}$ adalah sebesar 0.799045atau (79,9045\%), yang berarti bahwa besarnya pengaruh nilai tukar rupiah dan produk domestik bruto terhadap nilai ekspor tembakau di Indonesia adalah sebesar $0.799045 \quad(79,9045 \%)$, sedangkan yang dipengaruhi oleh observasi variabel lain diluar penelitian ini adalah 0.200955 (20,0955\%).

\section{Koefisien Korelasi (R)}

Untuk mengetahui hubungan nilai tukar rupiah dan produk domestik bruto terhadap nilai ekspor tembakau di Indonesia dapat dilihat pada nilai R. Berdasarkan hasil pengujian pada Tabel 4.5 dapat dilihat bahwa nilai $\mathrm{R}$ adalah:

$\mathrm{R}=\sqrt{\mathrm{R}^{2}}=\sqrt{0.799045}=0,8941197$ Oleh karena itu maka dapat disimpulkan bahwasannya hubungan antara nilai tukar rupiah dan produk domestik bruto terhadap nilai ekspor tembakau di Indonesia adalah berhubungan sangat kuat secara positif karena nilai 0,8941197 mendekati positif 1 $(+1)$.

\section{Pembahasan}

\section{Pengaruh Nilai Tukar Rupiah Terhadap Nilai Ekspor Tembakau di Indonesia}

Hasil penelitian ini sesuai dengan teori yang dikemukakan oleh Boediono(2001), dimana apabila nilai rupiah terdepresiasi terhadap nilai mata uang asing maka akan berdampak pada nilai ekspor yang naik.

Selain itu, hasil penelitian ini juga sejalan dengan hasil penelitian terdahulu yang telah dilakukan oleh Kadek Dwi Arya Pramanta, dkk (2017), dimana hasil penelitian menunjukkan bahwa kurs berpengaruh positif signifikan terhadap ekspor ikan tuna Indonesia tahun 19942015. Sama halnya dengan penelitian yang telah dilakukan oleh Mey Richa Madya Lestari (2011)dengan hasil penelitian bahwa nilai tukar 
$\left(\mathrm{X}_{2}\right)$ mempunyai pengaruh positif terhadap ekspor tekstil. Penelitian serupa juga dilakukan oleh Azmy Maulida, dkk (2016) tentang pengaruh harga tembakau internasional, jumlah produksi domestik dan nilai tukar terhadap nilai ekspor tembakau Indonesia (studi ekspor tembakau Indonesia tahun 1985-2014). Hasil dari penelitian tersebut adalah nilai tukar Rupiah $\left(\mathrm{X}_{3}\right)$ mempunyai pengaruh positif dan signifikan terhadap variabel nilai Ekspor Tembakau Indonesia (Y).

\section{Pengaruh Produk Domestik Bruto Terhadap Nilai Ekspor Tembakau Di Indonesia}

Kenaikan PDB meningkatkan daya beli serta kemampuan masyarakat untuk melakukan proses produksi lebih besar yang pada akhirnya bisa untuk diekspor ke negara lain. Bertambahnya surplus produksi yang ditandai dengan pertumbuhan PDB akan mendorong naiknya ekspor karena kelebihan output domestik akan disalurkan melalui ekspor. Dengan bertambahnya PDB suatu negara, maka jumlah produksi tembakau yang dihasilkan juga akan meningkat. Sehingga Tembakau yang di ekspor oleh Indonesia juga akan semakin meningkat, begitu juga sebaliknya.

Selain itu hasil penelitian ini juga sesuai dengan hasil penelitian terdahulu yang telah dilakukan oleh Kadek Dwi Arya Pramanta, dkk (2017), dimana hasil penelitian menunjukkan bahwa produk domestik bruto berpengaruh positif signifikan terhadap ekspor ikan tuna Indonesia tahun 1994-2015. Penelitian yang telah dilakukan oleh Mey Richa Madya Lestari (2011),dengan hasil penelitian yang menunjukkan bahwa PDB $\left(\mathrm{X}_{1}\right)$ mempunyai pengaruh positif terhadap ekspor tekstil. Kemudian penelitian yang telah dilakukan oleh Ari Mulianta Ginting (2013), dengan hasil penelitian yang menyatakan bahwa PDB Yang memiliki pengaruh yang positif dan signifikan terhadap ekspor.

\section{PENUTUP}

\section{Kesimpulan}

Berdasarkan hasil dari penelitian yang telah dilakukan, maka adapun kesimpulannya adalah sebagai berikut:
1. Secara parsial nilai tukar rupiah (Kurs) berpengaruh secara signifikan terhadap nilai ekspor tembakau di Indonesia tahun 19862016.

2. Secara parsial produk domestik bruto (PDB) berpengaruh secara signifikan terhadap nilai ekspor tembakau di Indonesia tahun 19862016.

3. Secara simultan nilai tukar rupiah (Kurs) dan produk domestik bruto (PDB) berpengaruh secara signifikan terhadap nilai ekspor tembakau di Indonesia tahun 1986-2016.

\section{Saran}

Berdasarkan hasil dari penelitian dan kesimpulan diatas, maka penulis memberikan beberapa saran sebagai berikut:

1. Diharapkan kepada pemerintah agar lebih memperhatikan tingkat investasi, inflasi, harga ekspor, jumlah produksi yang berhubungan atau yang berpengaruh terhadap nilai ekspor tembakau, dikarenakan dalam hal ini hasil penelitian telah membuktikan bahwa nilai tukar rupiah (Kurs) dan produk domestik bruto (PDB) berpengaruh positif dan signifikan terhadap nilai ekspor tembakau di Indonesia. Oleh karena itu pihak pemerintah dapat memberikan kontribusi ataupun memberikan kebijakan yang tepat supaya nilai ekspor tembakau Indonesia semakin meningkat. Selain itu, demi mempertahankan kedudukan Indonesia yang mana sebagai salah satu produsen utama tembakau dunia, pemerintah hendaknya berpartisipasi sehingga Indonesia tidak hanya dijadikan pasar namun juga dapat mengambil kesempatan di pasar industri tembakau dunia.

2. Diharapkan bagi peneliti selanjutnya yang ingin mendalami tentang hal-hal yang mempengaruhi nilai ekspor tembakau, agar dapat meneliti dan membahas dengan lebih baik lagi. Diharapkan juga dengan adanya dari penelitian ini nantinya dapat meningkatkan nilai ekspor tembakau Indonesia. Adapun dengan cara melihat serta mempelajari lebih lanjut mengenai hal-hal 
apa saja yang mempengaruhi nilai ekspor tembakau.

\section{DAFTAR PUSTAKA}

Amir, M. S. (2005). Ekspor Impor Teori Dan

Penerapannya. PPM: Jakarta.

Baldwin. (2005). Pengantar Ekonomi Industri

Dan Pendekatan Struktur, Prilaku dan

Kinerja Pasar. BPFE: Yogakarta.

Boediono. (2001). Ekonomi Makro Edisi

Keempat. BPFE: Yogyakarta.

Ghozali, I. (2005). Aplikasi Analisis

Multivariate. Badan Penerbit Universitas

Diponegoro: Semarang.

Ghozali, I. (2011). Aplikasi Analisis

Multivariate. BP Universitas Diponegoro:

Semarang.

Ghozali, I. (2012). Aplikasi Analisis

Multivariate. Universitas Diponegoro:

Semarang.

Ginting, A. M. (2013). Pengaruh Nilai Tukar

Terhadap Ekspor Indonesia. Buletin Ilmiah

Litbang Perdagangan, 7(1), 1-18.

Gujarati, D. (2006). Ekonometrika Dasar.

Terjemahan, Sumarsono Zain. Erlangga:

Jakarta.

Kurniawati, A. M., Yulianto, E., \& Abdillah, Y.

(2016). Pengaruh Harga Tembakau

Internasional, Jumlah Produksi Domestik

Dan Nilai Tukar Terhadap Nilai Ekspor

Tembakau Indonesia (Studi Ekspor

Tembakau Indonesia Tahun 1985-2014).

Jurnal Administrasi Bisnis (JAB), 38(2), 23-31.

Lestari, M. R. M. (2011). Analisis Faktor-Faktor

Yang Mempengaruhi Ekspor Tekstil Di

Indonesia Tahun 2005-2009. Jurnal

Ekonomi Pembangunan, 9(2), 174-183.

Mankiw, N. G. (2006). Teori Makro Ekonomi,

Edisi Ketiga. Erlangga: Jakarta.

Mankiw, N. G. (2007). Makroekonomi Edisi

Keenam Penerjemah Fitria Liza SE. dan

Imam Nurmawan SE. Erlanga: Jakarta.

Nachrowi, N. D. (2006). Ekonometrika Untuk

Analisis Ekonomi dan Keuangan.

Lembaga penerbit FE UI: Jakarta.

Pramanta, Kadek Dwi Arya. Dkk (2017).
Pengaruh Kurs, Negara Tujuan, Produksi, dan Produk Domestik Bruto Terhadap Ekspor Ikan Tuna Indonesia Tahun 19942015. E-Jurnal EP Unud, 6(12), 24082435.

Sagir, S. (2009). Kepita Selecta Ekonomi Indonesia. Kencana Predana Media Group: Jakarta.

Salvatore, D. (2007). Mikroekonomi Edisi Keempat. Erlangga: Jakarta.

Sukirno, S. (2000). Pengantar Teori Mikroekonomi. P.T Raja Grafindo Persada: Jakarta.

Sukirno, S. (2002). Teori Mikro Ekonomi Cetakan Keempat Belas. Rajawali Press: Jakarta.

Sukirno, S. (2006). Makro Ekonomi Teori Pengantar Edisi Ketiga. PT Raja Grafindo Persada: Jakarta.

Sukirno, S. (2008). Mikro Ekonomi Teori Pengantar. PT Raja Grafindo Persada: Jakarta.

Sukirno, S. (2010). Mikroekonomi Teori Pengantar. PT Raja Grafindo Persada: Jakarta.

Supranto, J. (2009). Statistik Teori Dan Aplikasinya Edisi Ketujuh. Erlangga: Jakarta.

Todaro, M. P. (2004). Pembangunan Ekonomi di Dunia Ketiga. Erlangga: Jakarta.

Triyono. (2008). Analisis Perubahan Kurs Rupiah Terhadap Dollar Amerika. Jurnal Ekonomi Pembangunan, 9(2), 156-167. 